\title{
Where are they now?
}

\section{Nature catches up with some past fraud investigations - and finds that, whether researchers are found to be guilty or innocent, the wounds are slow to heal.}

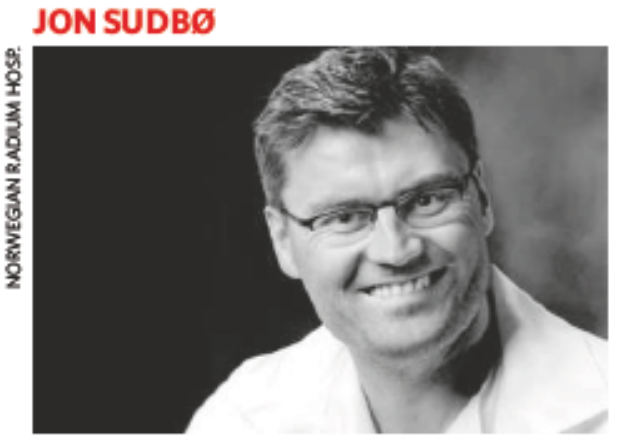

Jon Sudbø, a doctor and researcher at the Norwegian Radium Hospital in Oslo, confessed in January 2006 to fraud on an extraordinary scale (see Nature 439, 248-249; 2006). He admitted creating some 900 fictitious patients in a 2005 Lancet paper on the effect of certain painkillers on oral cancer risk in smokers, since retracted. An independent commission of inquiry was set up to discern the details of the fraud; last June it reported that the bulk of Sudbø's 30-plus publications were invalid because of the fabrication and manipulation of data.

Sudbø resigned the day after the commission released its report and was stripped of his medical and discipline degrees late last year. $\mathrm{He}$ is reportedly still in Oslo with his family but not working. Richard Horton, editor of The Lancet, co-hosted a meeting in Norway last month to establish what could belearnt from the case. $\mathrm{He}$ thinks that because Sudbø used public funds to pay for fraudulent work, he will probably face criminal proceedings.

L.O.-S.

\section{THEREZA IMANISHI-KARI}

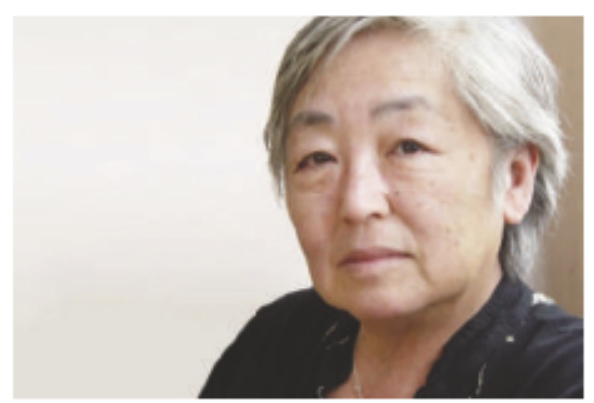

A 1986 paper in Cell on immunity in transgenic mice acquired international fame - not because of what it reported, but because of the slew of investigations it spurred. Among the paper's authors were Thereza Imanishi-Kari and Nobel laureate David Baltimore, then both at the Massachusetts Institute of Technology. A postdoc in Imanishi-Karis lab accused her of falsifying data in the Cell paper. The decade-long saga that followed involved a series of investigations, including one by the Energy and Commerce Congressional committee. Imanishi-Kari was cleared of all charges in 1996.

After doing no research for ten years, Imanishi-Kari reorganized a research programme at Tufts University in Medford, Massachusetts. Although pleased with the response of colleagues to her publications, she feels the case still overshadows her grant applications. "Being a woman in science is one kind of handicap; being wrongly accused is another," she says.

Henry Wortis, one of Imanishi-Kari's collaborators at Tufts, says people should judge her by her current work, published in leading journals such as Immunity. ${ }^{\alpha}$ That's the quality of work she's been unable to do for ten years, he says. "It's been a considerable loss to research."

L.O.-S.

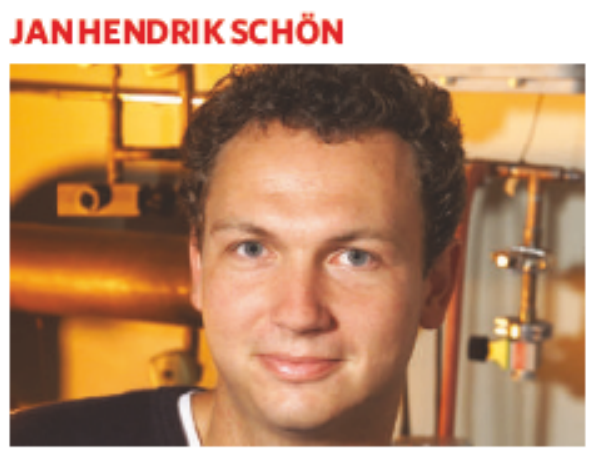

The fraud that came to light in the spring of 2002 is by far the most serious to strike physics in recent years. Jan Hendrik Schön was a rising star at Lucent Technologies' prestigious Bell Laboratories in Murray Hill, New Jersey, and author of a string of papers in Nature and Science. His reputation collapsed following a Bell Labs report that found Schön guilty of falsifying data in at least 16 papers on the electronic properties of new materials, such as organic films that might one day replace silicon-based electronics.

Schön's whereabouts are now unknown, and he has declined to comment on his research while investigations are continuing (the University of Konstanz in Germany is still assessing the work he did to earn his $\mathrm{PhD}$ there in the mid-1990s). But shock waves from the case have hit physicists, mainly in the shape of new research guidelines. Some of Schőn's co-authors were criticized for not spotting their colleagues misconduct, prompting the American Physical Society to issue new rules stating that coauthors should be accountable for important data in papers they sign off.

J.G.

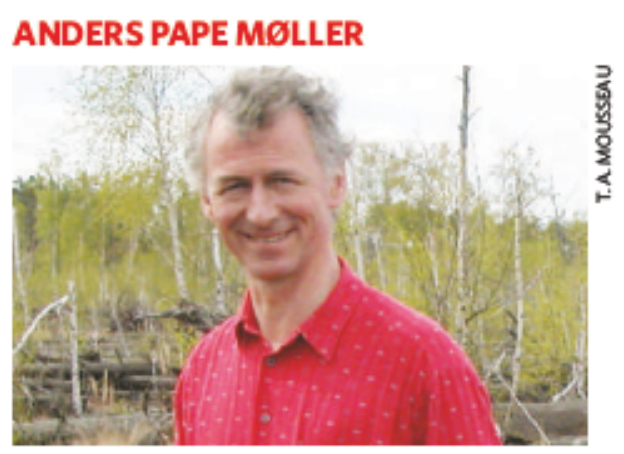

In late 2003, the Danish Committees on Scientific Dishonesty concluded that Anders Pape Møller, one of the world's leading experts in behavioural ecology, was guilty of 'scientific dishonesty'. A former colleague, Jørgen Rabøl, had accused Møller of using flawed data in a paper published in the journal Oikos. The paper has since been retracted.

Unconvinced, the National Council for Scientific Research in Paris, where Møller was and is still based, appointed an independent 'committee of wise men' to examine the case. In late 2004, the committee concluded that Møller was innocent: although it found that good lab practices hadn't been followed, it could not prove intent to commit scientific fraud. Møller did not respond to invitations for interview.

An impressive publication list in the past two years suggests that Møller's output has notbeen dimmed. But a collaborator, Timothy Mousseau at the University of South Carolina in Columbia, says that the consequences of the case rumble on. "Even though a complete investigation found no evidence, people get emotionally caught up in these kinds of interactions. There is no easy way to clear your name."

L.O.-S. 


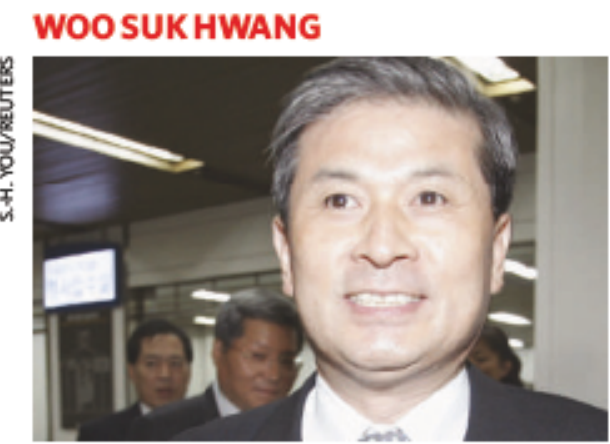

South Korea's stem-cell researcher Woo Suk Hwang is arguably the highest-profile scientific fraudster ever. In two hugely cited papers in Science in 2004 and 2005, Hwang daimed to have derived stem cells from cloned human embryos. But on 10 January 2006, Seoul National University announced after a fourweek investigation that all of his claims were fabricated.

The legal issues have been harder to clear up than the scientific ones. Prosecutors started an investigation the day that the university report was released, and delivered their own report on 12 May 2006. They charged Hwang with fraud, embezzlement, and violation of the country's bioethics law. But more than half-a-dozen hearings later, the court has still not reached a conclusion. The proceedings have not prevented Hwang from doing research: he is now carrying out animal cloning experiments athis new laboratory in Yongjin, 50 kilometres south of Seoul.

D.C.

\section{SHINICHI FUJIMURA}

In the 1980 s and 1990 s, amateur archaeologist Shinichi Fujimura was known throughout Japan for his 'divine hands', thanks to his discovering a string of stone artefacts that dated back to 700,000 years ago. Then in 2000 , Japanese newspaper Mainichi Shimbun published photos of Fujimura digging holes to bury tools that he later announced as major finds, and he confessed to fraud.

The Japanese Archaeological Association released the results of its final investigation in 2004. It concluded that all of the 168 sites dug by Fujimura had been faked - forcing Japanese history textbooks to rewrite their descriptions of the Palaeolithic period. The Tohoku Paleolithic Institute, where Fujimura held the post of deputy director, was also dissolved in 2004.

Fujimura, aged 56 years, was hospitalized for mental illness, and then reportedly remarried, changed his name and is now living quietly in a small town near the Pacific coast.

I.F.

\section{LUK VAN PARIJS}

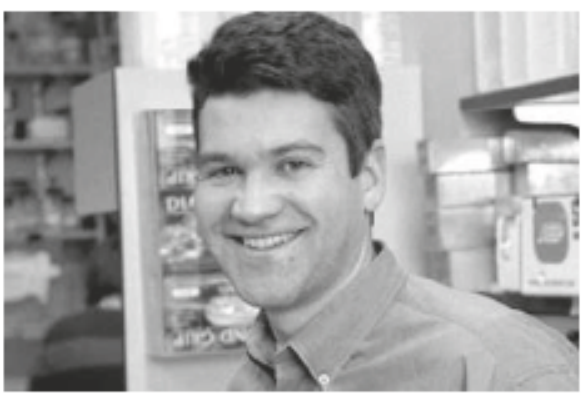

Once considered an exciting prospect in immunology and RNA interference, Luk Van Parijs was sacked from the Massachusetts Institute of Technology (MIT) in Cambridge in October 2005 after admitting that he had altered data in a published paper, unpublished manuscripts and grant applications. The
WOO SUK HWANG

Follow the story of the infamous South Korean stem-cell researcher online. www.nature.com/news/ specials/lwwang

institute inquiry that prompted the confession was sparked by allegations from some of his lab members.

Surprisingly, Van Parijs has co-authored a publication since the scandal, on a paper published in The Prostate in February 2006. The study's first author — urologist Qiang Zhang of Northwestern University in Chicago, Illinois - says that he and his co-authors included Van Parijs as an author because he had provided helpful ideas when giving a seminar in Zhang's department a few years earlier. He and other collaborators contacted by Nature have not communicated with Van Parijs since he left MIT.

L.O.-S.

\section{BENGÖ SEZEN}

In March 2006, Dalibor Sames, a chemist at Columbia University in New York, withdrew two papers and part of a third from the Journal of the American Chemical Society (JACS). Work done by graduate student Bengü Sezen, he said, couldn't be reproduced. The work was in the field of carbon-hydrogen bond functionalization, which aims to selectively break bonds within a molecule.

The case got a lot of coverage on the everlively chemistry blogs, and a few press outlets mentioned the issue, including Nature (440, $390-391 ; 2006$ ).

Sames is not commenting further until an inquiry is completed, and Columbia University says that it is against its policy to "comment on the existence or non-existence of any internal investigation into allegations of research misconduct ${ }^{\prime}$. But Sezen has vigorously defended herself in e-mails to the editor of $J A C S$ and the press.

E.M.

Lucy Odling-Smee, Jim Giles, Ichiko Fuyuno, David Cyranoski, Emma Marris

\section{How much fraud?}

Statistics relating to the prevalence of scientific fraud and misconduct are sparse. But here are a few.

\section{UNITED STATES}

Of 3,247 researchers funded by the National Institutes of Health who responded to a survey, $1.4 \%$ admitted to plagiarism and $0.3 \%$ admitted to falsification of data. $15.5 \%$ of responders said that they had changed the design, methodology or results of a study in response to pressure from a funding source (B. C. Martinson et al. Nature 435, 737-738; 2005).
In 2005, the Office of Research Integrity received 265 allegations of misconduct. Of 22 cases that it closed in that year, research misconduct was found in eight. Of theseeight cases, three were for falsification; two involved falsification and fabrication; two involved fabrication; and one involved plagiarism.

\section{UNITED KINGDOM}

Of 13 cases of suspected fraud brought to the Committee on Publication Ethics (COPE) between 1998 and 2003, seven were given up because of lack of documentation or lack of a response from the author or institution.

\section{JAPAN}

Of 1,323 research institutes that responded to a Science Council of Japan survey in 2006 , only $13.4 \%$ had guidelines on what behaviours are defined as misconduct and how to act if misconduct is reported. Just $12.4 \%$ of institutes had discussed dishonest behaviour with their researchers in thepast ten years.

\section{GERMANY}

The ombudsmen of the German Research Foundation (DFG) were called in 45 cases of misconduct in 2004 , and took up 36 of them. Of these 36 cases, misconduct was found in one investigation.

\section{DENMARK}

Of 25 investigations that were concluded by the Danish Committees on Scientific Dishonesty between 2003 and 2005, dishonest behaviour was found in two of them. 